\title{
Tillering affected by sowing density and growth regulators in wheat
}

\section{Perfilhamento do trigo afetado pela densidade de semeadura e aplicação de reguladores vegetais}

\author{
Samuel Luiz Fioreze ${ }^{*}$; João Domingos Rodrigues ${ }^{2}$
}

\begin{abstract}
Tillering capacity of wheat is highly influenced by environmental conditions and management practices. This research had as objective to evaluate tiller emission, survival and contribution to grain final yield affected by increasing sowing densities and growth regulators application in wheat. The experiment was conducted under completely randomized block design, with subdivided plots and four replications. Treatments consisted of four plant densities $\left(30,50,70\right.$ and 90 plants $\left.\mathrm{m}^{-1}\right)$ combined with the application of growth regulators [control, (IBA+GA+KT), Trinexapac-Ethyl and $(\mathrm{IBA}+\mathrm{GA}+\mathrm{KT})+$ TrinexapacEthyl]. Tiller emission, contribution to dry matter accumulation and grain yield, survival and yield potential in relation to the main stem were evaluated, as well as yield components and grain final yield. The application plant growth regulators did not affect tiller emission or any other yield parameters related to the main stem. Increasing plant densities reduced tiller emission and dry matter accumulation, which led to lower tiller contribution and yield potential. Reduced plant densities increased grain yield due to higher grain number and mass per ear, making up for lower number of ears per area.
\end{abstract}

Key words: Triticum aestivum L., yield potential, assimilate accumulation, IBA+GA+KT, TrinexapacEthyl

\section{Resumo}

A capacidade de perfilhamento do trigo é altamente influenciada pelo ambiente e as práticas de manejo. Objetivou-se avaliar a emissão, a sobrevivência e a participação de perfilhos de trigo na produção de grãos de trigo em densidades crescentes de plantas e submetido à aplicação de reguladores vegetais. $\mathrm{O}$ delineamento experimental utilizado foi o de blocos casualizados em esquema de parcelas subdivididas com quatro repetições. As parcelas constaram de quatro densidades de semeadura $(30,50,70$

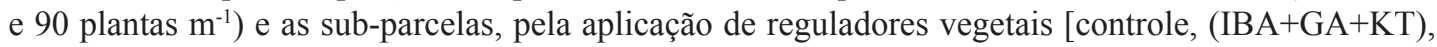
Etil-Trinexapac e (IBA+GA+KT) + Etil-Trinexapac]. Foram avaliados a emissão, a sobrevivência e o potencial produtivo de perfilho em relação ao colmo principal bem como os componentes da produção e a produtividade de grãos da cultura. A aplicação dos reguladores vegetais não afetou a emissão de perfilhos e os parâmetros produtivos do colmo principal em plantas de trigo. A redução na emissão de perfilhos e do acúmulo de matéria seca foi observada para elevadas densidades de plantas, reduzindo sua participação e do potencial produtivo. A maior produção de grãos nas menores densidades de plantas ocorreu pelo aumento do número e da massa de grãos por espiga, compensando o menor número de espigas por metro quadrado.

Palavras-chave: Triticum aestivum L., potencial produtivo, acúmulo de assimilados, IBA+GA+KT, Etil-Trinexapac

\footnotetext{
Prof. Auxiliar do Dept ${ }^{\circ}$ de Ciências Agronômicas, Curso de Agronomia ,Universidade Federal de Santa Catarina, UFSC, Campus de Curitibanos, Curitibanos, SC, Brasil. E-mail: s.fioreze@ufsc.br

2 Prof. Titular do Dept ${ }^{\circ}$ de Botânica, Universidade Estadual Paulista Júlio de Mesquita Filho, UNESP, Instituto de Biociências, Distrito de Rubião Júnior, Botucatu, SP, Brasil. E-mail: mingo@ibb.unesp.br

* Author for correspondence
} 


\section{Introduction}

Tiller emission, development and survival have been reported as extremely important in wheat crop (ALVES; MUNDSTOCK; MEDEIROS, 2000; VALÉRIO et al., 2008; VALÉRIO et al., 2009) and pointed out as the main quantitative component to influence grain yield (HARTWIG et al., 2007). Tillering may affect wheat yield positively or negatively depending on availability of natural resources such as water, light and nutrients (ELHANI et al., 2007).

The relationship between tillers and the main stem is influenced by environmental conditions during primordia initiation and in subsequent stages (ALMEIDA; MUNDSTOCK, 2001). The effects of competition are relevant in tiller emergence and may affect directly final yield and yield components (OZTURK; CAGLAR; BULUT, 2006). For the same reason, plant density is especially important in wheat for it influences final yield and yield components (OZTURK; CAGLAR; BULUT, 2006) according to cropping conditions (LLOVERAS et al., 2004).

Hormonal balance involved in tiller emission and development is rather complex and influenced by auxin (Ax) and cytokinin (CK); these hormones are related to apical dominance and dormancy breaking of lateral buds (VALÉRIO et al., 2009; VEIT, 2006). Altering hormonal balance through the application of growth regulators may significantly improve plant development, although there are few studies about effects in wheat. This research had as objective to evaluate tiller emission, survival and contribution to grain final yield affected by sowing densities and growth regulators application in wheat.

\section{Material and Methods}

The experiment was carried out from April to August 2010 in Botucatu (SP), Brazil (2249' S, $48^{\circ} 25^{\prime} \mathrm{W}$ and $770 \mathrm{~m}$ asl). According to Köeppen's classification, climate is $\mathrm{Cwa}$, which corresponds to tropical altitude with dry winter and hot wet summer.
Soil in the area was a clayey Hapludox (FAO, 2006) with the following physical and chemical attributes: clay: $420.0 \mathrm{~g} \mathrm{~kg}^{-1}$; organic matter: $21.0 \mathrm{~g} \mathrm{dm}^{-3} ; \mathrm{pH}$ $\left(\mathrm{CaCl}_{2}\right)$ : 5.8; $\mathrm{Ca}, \mathrm{Mg}, \mathrm{K}$ and $\mathrm{Al}: 53.0,28.0,2.7$ and $1.0 \mathrm{cmol}_{\mathrm{c}} \mathrm{dm}^{-3}$, respectively; $\mathrm{P}_{\text {resin }}: 33.0 \mathrm{mg} \mathrm{dm}^{-3}$; base saturation: $74 \%$.

The experimental design was the completely randomized block, with subdivided plots and four replications. Main plots consisted of four plant densities $\left(30,50,70\right.$ and 90 plants $\left.\mathrm{m}^{-1}\right)$. Subplots consisted of the application of growth regulators [control, (IBA+GA+KT), Trinexapac-Ethyl and $(\mathrm{IBA}+\mathrm{GA}+\mathrm{KT})+$ Trinexapac-Ethyl], totaling 64 experimental units. Each unit or subplot consisted of 13 rows with $10 \mathrm{~m}$ length spaced $0.17 \mathrm{~m}$. The useful area was the seven central rows, except 1.0 $\mathrm{m}$ of each extremity, totaling $9.18 \mathrm{~m}^{2}$.

Wheat cultivar IAC 370, with intermediate height and good adaptability in the cropping conditions (EMBRAPA, 2010), was sown under no tillage system in succession to soybean. Sowing densities were $38,63,88$ and 113 seeds $\mathrm{m}^{-1}$, which were adjusted according to results of the germination test (BRASIL, 2009). Sowing was carried out mechanically at $4 \mathrm{~cm}$ depth with a seed drill.

Base fertilization consisted of $160 \mathrm{~kg} \mathrm{ha}^{-1}$ of the NPK formula 08-28-16. Side dressing consisted of 45 and $30 \mathrm{~kg} \mathrm{ha}^{-1}$ of $\mathrm{N}$ and $\mathrm{K}$, respectively, applied as ammonium sulphate and potassium chloride at tillering stage; additionally, $45 \mathrm{~kg} \mathrm{ha}^{-1}$ of $\mathrm{N}$ was applied at the end of tillering stage, which corresponded to stages 2 and 5 in Feeks' classification (LARGE, 1954). Water availability was monitored in soil based on a set of mercury tensiometers installed down to $20 \mathrm{~cm}$ depth and irrigation took place whenever mercury column reached $40 \mathrm{~cm}$ height. Accumulated rainfall and total irrigation depth during the cycle was $315 \mathrm{~mm}$, which is considered optimal for wheat requirements (EMBRAPA, 2010).

The application of $500 \mathrm{~mL} \mathrm{ha}^{-1}$ of IBA $+\mathrm{GA}+\mathrm{KT}$ (0.05 mg L-1 of indolbutiric acid, $0.05 \mathrm{~g} \mathrm{L-1}$ 
gibberellic acid, and $0.09 \mathrm{~g} \mathrm{~L}^{-1}$ of kinetin) took place at the beginning of tillering (14 days after seedling emergence - DAE) and Trinexapac-Ethyl was applied at $400 \mathrm{~mL} \mathrm{ha}^{-1}\left(100 \mathrm{~g} \mathrm{ha}^{-1}\right.$ a.i) rate when the first node was visible in the main stem (60 DAE), which corresponded to stages 2 and 6 at Feeks' classification (LARGE, 1954), respectively. Leaf application of both growth regulators were conducted with a pressurized boom sprayer equipped with 110.02 flat spray tips adjusted to volume of $150 \mathrm{~L} \mathrm{ha}^{-1}$.

Tiller emission was evaluated throughout tillering stage every four days. Forty-five plants per plot were evaluated, distributed at random in three distinct spots. Tillers were identified according to instructions from Masle (1985): tillers were named after letter T, followed by the number of the leaf/ node where that tiller was originated from [MS main stem; T0 - tiller originated from the coleoptile node; T1 - tiller originated from the node of the first leaf in the main stem; Tth - tiller originated from the node of the $(n)^{\text {th }}$ leaf in the main stem]. Tillers were identified using colored cotton threads; plants were later used for the evaluation of dry matter accumulation and yield components.

Dry matter accumulation of both tillers and main stem were determined at the end of tillering (42 DAE) and in the beginning of the reproductive stage (anthesis) (73 DAE). In each stage, 10 plants with their tillers previously identified were sampled for dry matter evaluation of leaves, stem+leaf sheath and reproductive structures. Yield components were determined in 15 plants per plot through the number of spikelets per spike, number of grains per spikelet, number of grains per spike and mass of grains per spike for both the main stem and tillers. The number of spikes $\mathrm{m}^{-2}$ and the increase in the number of spikes after tiller emission were also evaluated. Grain yield $\left(\mathrm{kg} \mathrm{ha}^{-1}\right)$ adjusted to $13 \%$ moisture and mass of 1,000 grains were calculated right after harvest.

Tiller survival was determined by comparing the number of tillers at the end of tillering and anthesis with the number of tillers at the end of the cycle. Tiller contribution to final grain yield was calculated by the relationship between the final grain production per plant and the sum of all tillers production. Average yield potential of tillers was calculated by the relation between the average grain yield per tiller and the average grain yield in the main stem, considering that main stem shows $100 \%$ as yield potential.

Data was submitted to variance analysis by the $F$ test $(p \leq 0.05)$. Means for growth regulators were compared by the Tukey test $(\mathrm{p} \leq 0.05)$ and plant densities by regression analysis.

\section{Results and Discussion}

Increasing plant density significantly reduced tiller emission per plant and per $\mathrm{m}^{2}$ throughout tillering stage (Table 1), with minimum values for the highest densities (Figures 1 and 2). The number of tillers per plant was close to zero in the highest densities, similarly to the number of tillers $\mathrm{m}^{-2}$. In this case, this is due to adjustment in the number of plants per area, mainly in the end of tillering (Figures 2d, 2e and 2f).

Application of growth regulators did not affected tiller emission and dry matter accumulation. Is important highlight that the application of Trinexapac-Ethyl was carried out in the end of tillering. Until this stage, only the application of $\mathrm{IBA}+\mathrm{GA}+\mathrm{KT}$ had been accomplished whit the objective of to stimulate the tiller emission, mainly for higher plant densities, result no verified. The beginning of plant elongation in wheat can be observed at the mean stem, then for the tillers, thus, the inhibition of mean stem elongation (TrinexapacEthyl application) could result in better development and dry matter accumulation on tillers and great survival rates. However, this result was not verified. Hormonal balance involved in tiller emission and its relationship with mean stem need, wherefore, more research, so the plant growth handling, by growth regulators could become a tool to improve the yield in wheat. 
Table 1. Variance analysis (F values) of number of tillers per plant and square meter affected by plant densities and growth regulators in wheat (IAC 370). Botucatu (SP), Brazil, 2010.

\begin{tabular}{|c|c|c|c|c|c|c|c|}
\hline \multicolumn{8}{|c|}{ Number of tillers per plant } \\
\hline & $14 \mathrm{DAE}^{1}$ & $18 \mathrm{DAE}$ & $22 \mathrm{DAE}$ & $26 \mathrm{DAE}$ & $30 \mathrm{DAE}$ & $34 \mathrm{DAE}$ & $38 \mathrm{DAE}$ \\
\hline Bloc & 1,03 & 1,43 & 3,76 & $5,34 *$ & $8,88 * *$ & $5,58^{*}$ & $5,76^{*}$ \\
\hline Densities (D) & $4,73^{*}$ & $39,01 * *$ & $52,83^{* *}$ & $75,92 * *$ & $135,06 * *$ & 126,11 & $120,05 * *$ \\
\hline Growth regulator $(\mathrm{G})$ & 2,11 & 2,81 & 1,29 & 0,77 & 1,01 & 1,41 & 1,11 \\
\hline $\mathrm{D} \times \mathrm{G}$ & 1,82 & 2,14 & 1,89 & 1,62 & 0,99 & 1,34 & 1,01 \\
\hline $\mathrm{CV}(\%)^{1}$ & 301,54 & 68,81 & 47,87 & 32,17 & 21,01 & 21,26 & 22,72 \\
\hline $\mathrm{CV}(\%)^{2}$ & 189,73 & 43,49 & 31,65 & 23,79 & 19,73 & 17,86 & 16,12 \\
\hline \multicolumn{8}{|c|}{ Number of tillers per square meter } \\
\hline & $14 \mathrm{DAE}$ & $18 \mathrm{DAE}$ & $22 \mathrm{DAE}$ & $26 \mathrm{DAE}$ & $30 \mathrm{DAE}$ & $34 \mathrm{DAE}$ & $38 \mathrm{DAE}$ \\
\hline Bloc & 1,71 & 1,78 & 3,39 & 3,78 & $5,15^{*}$ & $11,04 * *$ & $17,04 * *$ \\
\hline Densities (D) & $4,14^{*}$ & $11,91 * *$ & $10,09 * *$ & $10,12 * *$ & $11,29 * *$ & $30,01 * *$ & $48,69 * *$ \\
\hline Growth regulator $(\mathrm{G})$ & 1,99 & 2,15 & 0,69 & 0,39 & 0,64 & 1,71 & 1,51 \\
\hline $\mathrm{D} \times \mathrm{G}$ & 1,55 & 1,35 & 1,39 & 1,35 & 0,79 & 1,13 & 0,88 \\
\hline CV $(\%)^{1}$ & 254,34 & 85,76 & 65,85 & 47,94 & 32,87 & 15,19 & 12,93 \\
\hline $\mathrm{CV}(\%)^{2}$ & 177,78 & 53,26 & 35,56 & 26,71 & 22,78 & 20,54 & 19,64 \\
\hline
\end{tabular}

*, **Significant by the $\mathrm{F}$ test $\left(\mathrm{p}<0.05\right.$ and $<0.01$ respectively); ${ }^{1}$ plot coefficient of variation; ${ }^{2}$ subplot coefficient of variation; ${ }^{3}$ days after emergence.

Source: Elaboration of the authors.

Tillering potential of each genotype is the main factor involved with the performance of a given material and its interactions with the environment (VALÉRIO et al., 2009). Wheat cultivar IAC 370 showed high capacity for tiller emission under low cropping densities; however, it was significantly influenced by the competition among plants increased within the row. According to Destro et al. (2001), wheat plants cropped under low densities produce more tillers and show similar number of spikes $\mathrm{m}^{-2}$ in the end of the cycle compared to denser cropping.

Apical dominance is affected by the quality of the light absorbed by phytocromes, i.e., by the relationship between red and far red wavelengths from total radiation (BALLARÉ et al., 1992). Almeida e Mundstock (2001) observed that light quality improved by adding red radiation increased tiller emission and improved dry matter distribution between the tillers and the main stem in wheat; conversely, poor light quality, obtained by adding extreme red radiation inter rows, led to high dry matter accumulation in the main stem. Therefore, it is noticeable there is positive interaction between light and hormones related to the signaling cascade that control tiller emission and development in grasses (ALVES; MUNDSTOCK; MEDEIROS, 2000).

Competition among plants increased along with sowing density (Table 2). Under lower densities, increased dry matter accumulation was a clear effect of a high number of tillers in plants cropped in this conditions (Figures 1 and 2), once every tiller emerged is consisted of its own stem and leaves, which actively take part in processes of assimilation and dry matter accumulation. Under higher densities, reduced dry matter accumulation at the end of tillering (Figure 3) and anthesis (Figure 4) stages was observed. The application of growth regulators did not influence dry matter accumulation per plant nor per area. 
Figure 1. Number of tillers per plant affected by plant densities in wheat (IAC 370) at 18 (a), 22 (b), 26 (c), 30 (d), 34 (e) and 38 (f) days after seedling emergence. Botucatu (SP), Brazil, 2010. **p $<0.01$.
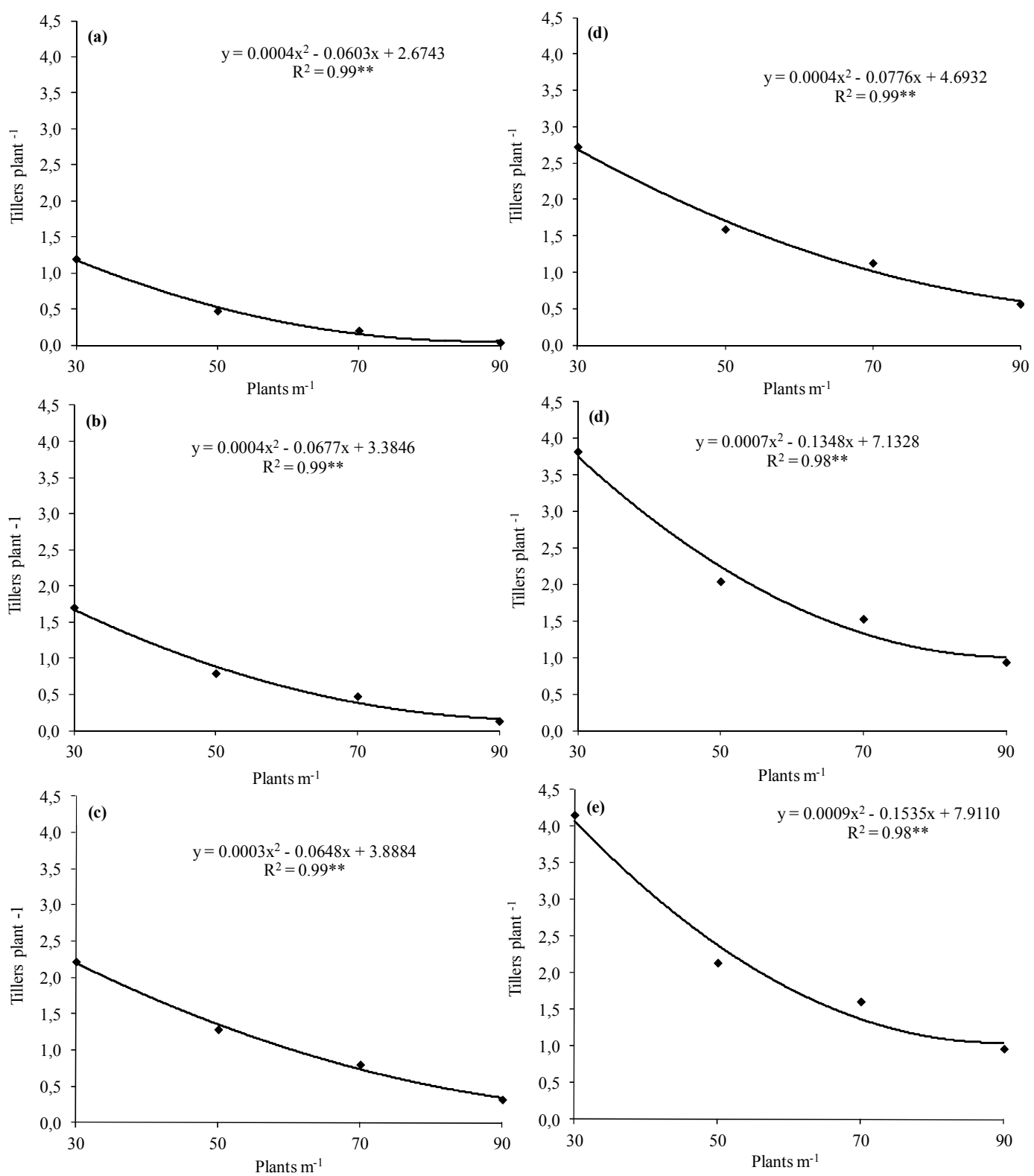

Source: Elaboration of the authors. 
Figure 2. Number of tillers per $\mathrm{m}^{2}$ affected by plant densities in wheat (IAC 370) at 18 (a), 22 (b), 26 (c), 30 (d), 34 (e) and 38 (f) days after seedling emergence. Botucatu (SP), Brazil, 2010. ${ }^{* *} p<0.01$.
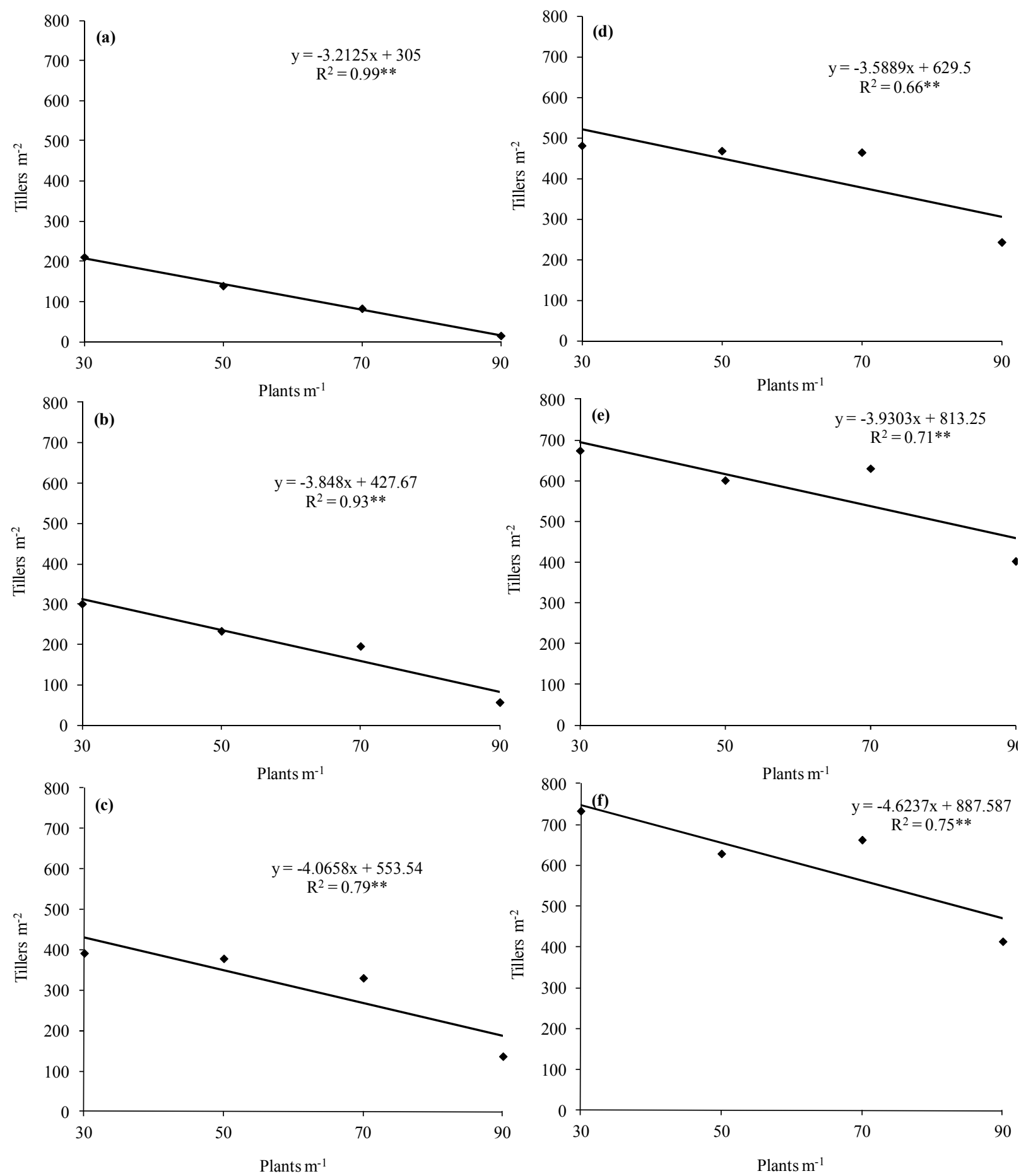

Source: Elaboration of the authors. 
Table 2. Variance analysis ( $F$ values) of dry matter accumulation in the main stem (MSDW), leaves (LDW), total (TDW) and dry matter ratio between stem and leaves (S/L) at the end of tillering and dry matter accumulation in the main stem (MSDW), leaves (LDW), spikes (SDW) and total per plant (TDW) at anthesis stage affected by plant densities and growth regulators in wheat (IAC 370). Botucatu (SP), Brazil, 2010.

\begin{tabular}{ccccccccc}
\hline & \multicolumn{4}{c}{ End of tillering } & \multicolumn{4}{c}{ Anthesis } \\
\hline & MSDW & LDW & TDW & S/L & MSDW & LDW & SDW & TDW \\
\hline Bloc & $4,73^{*}$ & $7,68^{* *}$ & $6,379^{* *}$ & 0,47 & 0,39 & 3,08 & 0,23 & 0,62 \\
Densities (D) & $65,86^{* *}$ & $86,38^{* *}$ & $79,29^{* *}$ & $6,24^{*}$ & $96,78^{* *}$ & $155,30^{* *}$ & $25,69^{* *}$ & $88,12^{* *}$ \\
Growth regulator (G) & 0,53 & 0,69 & 0,64 & 0,13 & 1,04 & 0,87 & 0,42 & 0,76 \\
D x G & 0,61 & 0,69 & 3,61 & 1,07 & 0,06 & 1,18 & 1,26 & 1,33 \\
\hline CV (\%) & 25,11 & 18,84 & 21,07 & 10,88 & 19,13 & 16,13 & 35,43 & 20,16 \\
CV (\%) & 22,19 & 19,24 & 19,98 & 10,08 & 18,71 & 19,54 & 23,90 & 18,32 \\
\hline
\end{tabular}

* $* *$ Significant by the $\mathrm{F}$ test $\left(\mathrm{p}<0.05\right.$ and $<0.01$ respectively); ${ }^{1}$ plot coefficient of variation; ${ }^{2}$ subplot coefficient of variation; Source: Elaboration of the authors.

Figure 3. Dry matter accumulation in the main stem (a), leaves (b), total (c) and dry matter ratio between stem and leaves (d) at the end of tillering affected by plant densities in wheat (IAC 370). Botucatu (SP), Brazil, 2010. **p $p 0.01$
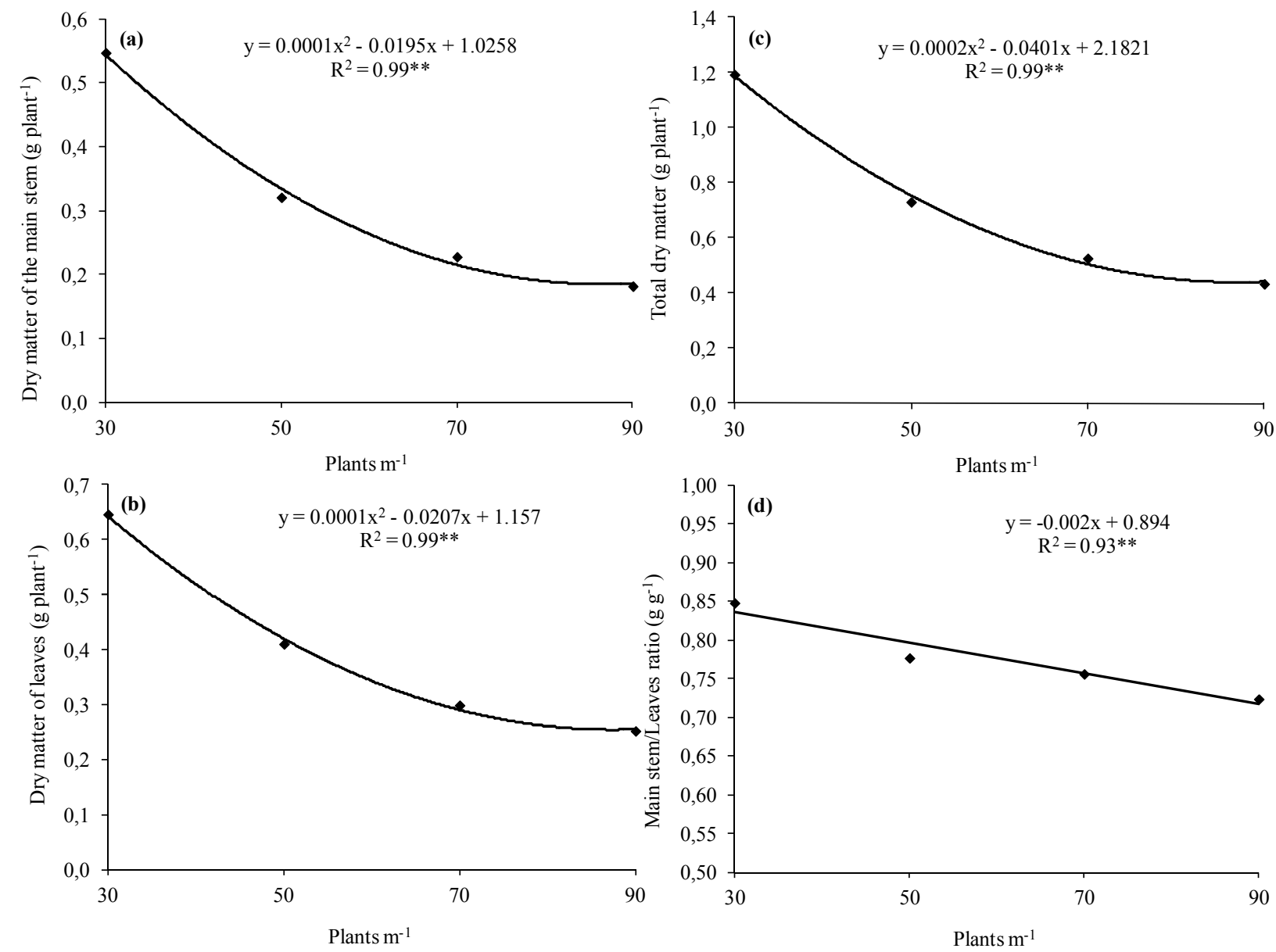

Source: Elaboration of the authors. 
Figure 4. Dry matter accumulation in the main stem (a), leaves (b), spikes (c) and total per plant (d) at anthesis stage affected by plant densities in wheat (IAC 370). Botucatu (SP), Brazil, 2010. ${ }^{*} p<0.01$.
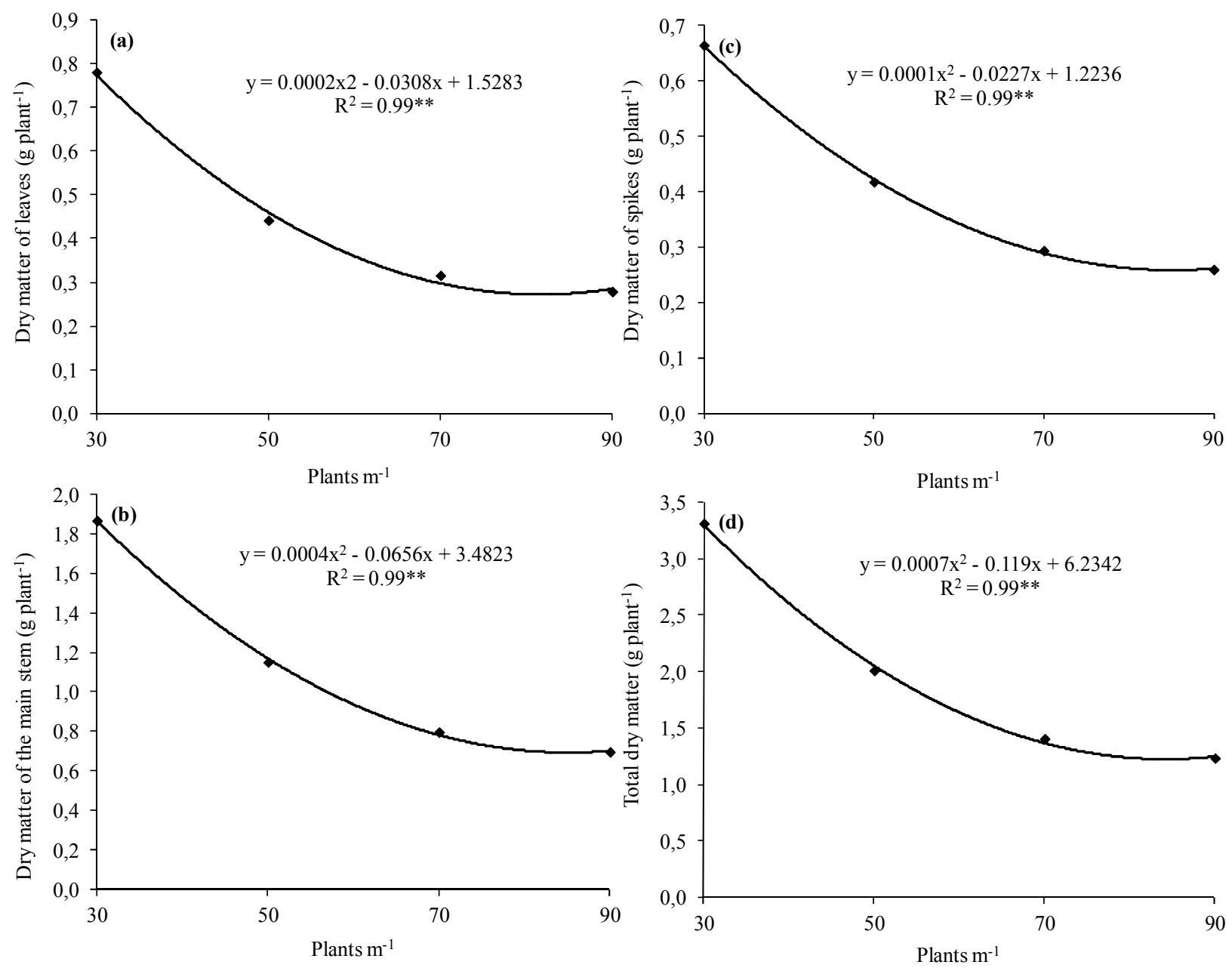

Source: Elaboration of the authors.

Under environmental conditions of good light quality, observed in reduced plant densities, dry matter accumulation in tillers may be related to improved development of leaves, mainly due to a higher number of cells (ALMEIDA; MUNDSTOCK, 2001); this is in turn related to the emission of new leaves and tillers (SKINNER; NELSON, 1994). As plant density was higher, leaf development was reduced in relation to the main stem (Figure $3 \mathrm{~d}$ ) once plants within the same row were closer to each other. Assimilate accumulation in pre-anthesis stage plays an important role in grain filling and, consequently, wheat yield. From this stage on, production of photoassimilates is reduced due to leaf senescence, which is even more accentuated under water deficit conditions and high-demanding sink (ELHANI et al., 2007). Hence, reserves from stems are essential to maintain appropriate yield levels (BLUM, 1998).

Total dry matter accumulation per area was not influenced by plant densities, demonstrating the flexibility of wheat plants to develop under low-density conditions, mainly at anthesis stage. Tiller emission, as well as dry matter accumulated individually by each plant, worked as a compensation mechanism for the reduced number of plants per area. Valério et al. (2009) reported that wheat 
capacity to make up for a lower number of plants through tiller emission and assimilate accumulation is variable and depends on genotype.

In wheat, grain yield consists of several individual components such as the number of spikes per plant, spikelets per spike, grains per spike, grains per spikelet and grain mass, but directly depends on genotype and environmental conditions (CRUZ et al., 2003). Grain yield of cereals cropped under constant populations may be obtained mainly through three components, i.e. number of spikes per area, number of grains per spike and grain mass; these in turn may vary independently until a given limit (NEDEL, 1994).
Increasing plant density within the row reduced yield components (Table 3 ) individually (Figure 5) as a consequence of intense competition among plants and thus low dry matter accumulation per plant, mainly at anthesis stage. The number of grains $\mathrm{m}^{-2}$ is closely related to plant capacity in biomass accumulation and transference to reproductive structures at pre-anthesis (RODRIGUES et al., 2002). Path analysis in wheat shows that shoot biomass accumulation is one of the main components to influence final yield (OKUYAMA; FERERIZZI; BARBOSA NETO, 2004), along with the number of spikes per area and grains per spike.

Table 3. Variance analysis (F values) of rachis length (RL), number of fertile spikelets (FE), number of grains per spike (NGS) mass of grains per spike (MGS), number of spikes per $\mathrm{m}^{2}$ (NSM), increase in the number of spikes (INS), grain yield (GY) and mass of 1,000 grains (TGW) affected by plant densities and growth regulators in wheat (IAC 370). Botucatu (SP), Brazil, 2010.

\begin{tabular}{ccccccccl}
\hline & RL & FE & NGS & MGS & NSM & INS & GY & TGW \\
\hline Bloc & 1,80 & 0,99 & 1,29 & 1,33 & 0,78 & 0,65 & 0,14 & 7,16 \\
Densities (D) & $171,83^{* *}$ & $101,16^{* *}$ & $103,47^{* *}$ & $114,81^{* *}$ & $73,42^{* *}$ & $70,88^{* *}$ & $8,54^{* *}$ & $7,73^{* *}$ \\
Growth regulator (G) & 0,62 & 0,52 & 0,50 & 0,49 & 0,19 & 0,24 & 0,57 & $5,62^{* *}$ \\
D x G & 1,02 & 0,87 & 1,06 & 1,04 & 0,61 & 0,57 & 1,78 & 0,60 \\
\hline CV (\%) & 12,86 & 16,32 & 18,35 & 17,49 & 10,67 & 66,41 & 35,07 & 2,46 \\
CV $(\%)^{2}$ & 18,02 & 20,12 & 21,26 & 22,48 & 11,80 & 59,89 & 13,70 & 4,81 \\
\hline
\end{tabular}

*, **Significant by the $\mathrm{F}$ test $\left(\mathrm{p}<0.05\right.$ and $<0.01$ respectively); ${ }^{1}$ plot coefficient of variation; ${ }^{2}$ subplot coefficient of variation. Source: Elaboration of the authors.

Maintaining final grain yield under different plant densities is possible by compensating other yield components, once wheat is highly capable of modifying or adjusting some of them whenever another is deficient or excessive (FREEZE; BACON, 1990). Although higher tiller emission was attributed to lower plant densities (Figures 1 and 2), it was not sufficient to make up for the number of spikes $\mathrm{m}^{-2}$, upon comparing to the denser cropping (Figure 6a). Nevertheless, increased number of spikes $\mathrm{m}^{-2}$ in lower populations is indicative of this cultivar to potentially compensate an unoccupied area with tiller emission and maintenance, once it is a characteristic highly dependent on genotype (VALÉRIO et al., 2009).
Even with reduced number of spikes per area (Figure 6a), higher yields were obtained with lower plant densities; on the contrary, yield was reduced as the number of plants within the row was increased (Figure 6c). These results show that plant density effects on dry matter accumulation (Figures 3 and 4) and, consequently, on the number and mass of grains per spike (Figure 5) were determinant to expressing yield potential in the conditions of this experiment. 
Figure 5. Rachis length (a), number of fertile spikelets (b), number of grains per spike (c) and mass of grains per spike (d) affected by plant densities in wheat (IAC 370). Botucatu (SP), Brazil, 2010. **p $<0.01$.
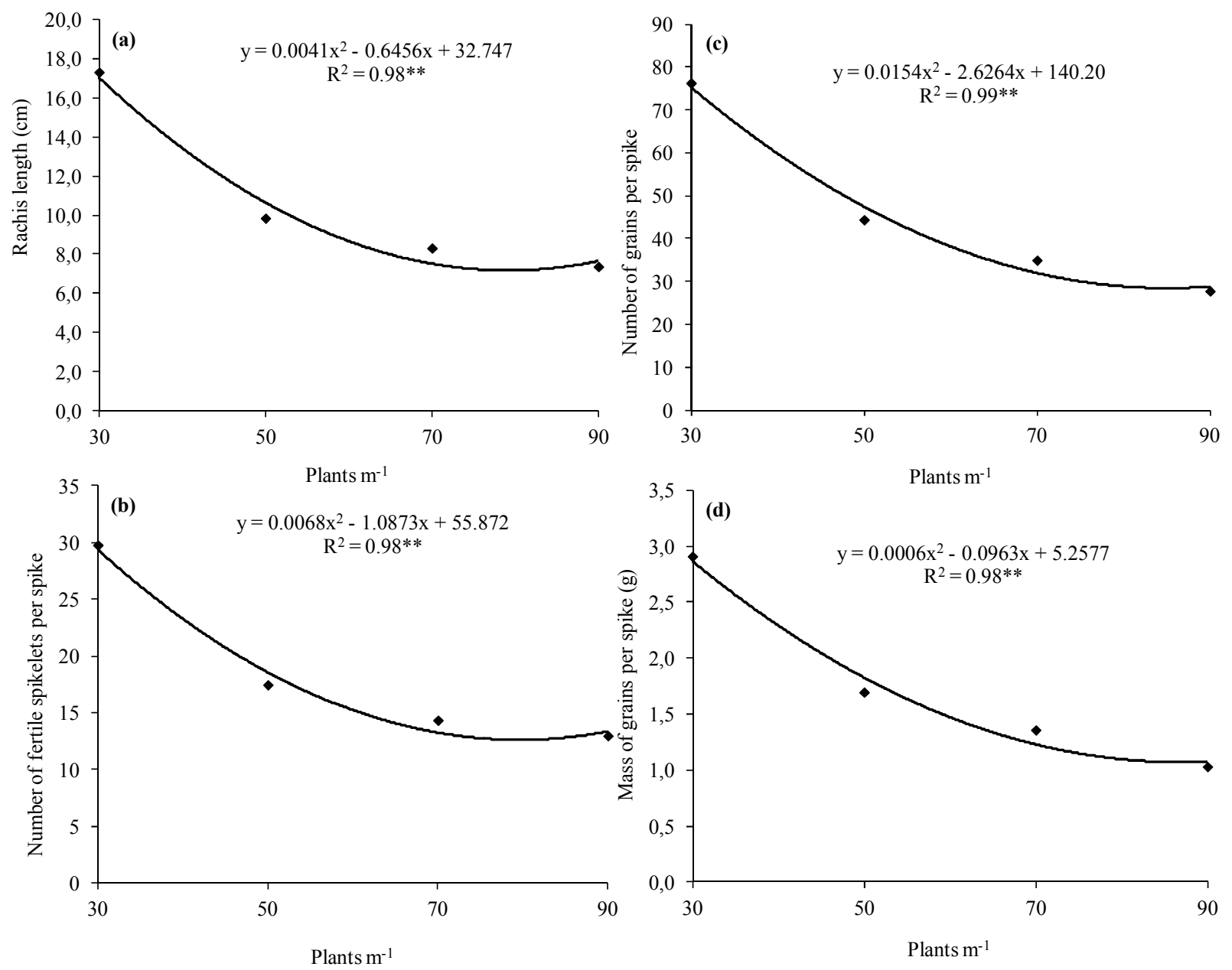

Source: Elaboration of the authors.

Trinexapac- Ethyl application reduced significantly the mass of 1,000 grains $(41.1 \mathrm{~g})$ compared to the control (43.4 g). Although grain mass is an important component, final yield was not reduced. Growth regulators did not differ significantly from each other, even considering the combination between them. Results of grain mass after the application of growth regulators in wheat have been controversial. Some studies have shown positive (ZAGONEL et al., 2002) or negative effects (ESPINDULA et al., 2009); others have also shown variable responses depending on the genotype (ZAGONEL; FERNANDES, 2007).

The number of tillers $\mathrm{m}^{-2}$ at anthesis and by the end of the cycle (Table 4 and Figure $7 \mathrm{ab}$ ) varied as showed for the end of tillering (Figure 1f). The number of tillers was lower in denser populations. Nevertheless, higher abortion rate was observed during the cycle for all densities (Figure 7c). Competition effects are determinant for tiller development (OZTURK; CAGLAR; BULUT, 2006). Growth rate of leaves from both main stem and tillers are similar under ideal conditions (MASLE, 1985); even so, competition among plants for light in initial growth stages limits tiller emission under high plant densities. In these conditions, apical dominance is intensified by a faster development of the main stem, which prevents lateral buds from develop (VEITT, 2006). 
Figure 6. Number of spikes per $\mathrm{m}^{2}$ (a), increase in the number of spikes (b), grain yield (c) and mass of 1,000 grains (d) affected by plant densities in wheat (IAC 370). Botucatu (SP), Brazil, 2010. **p $<0.01$.
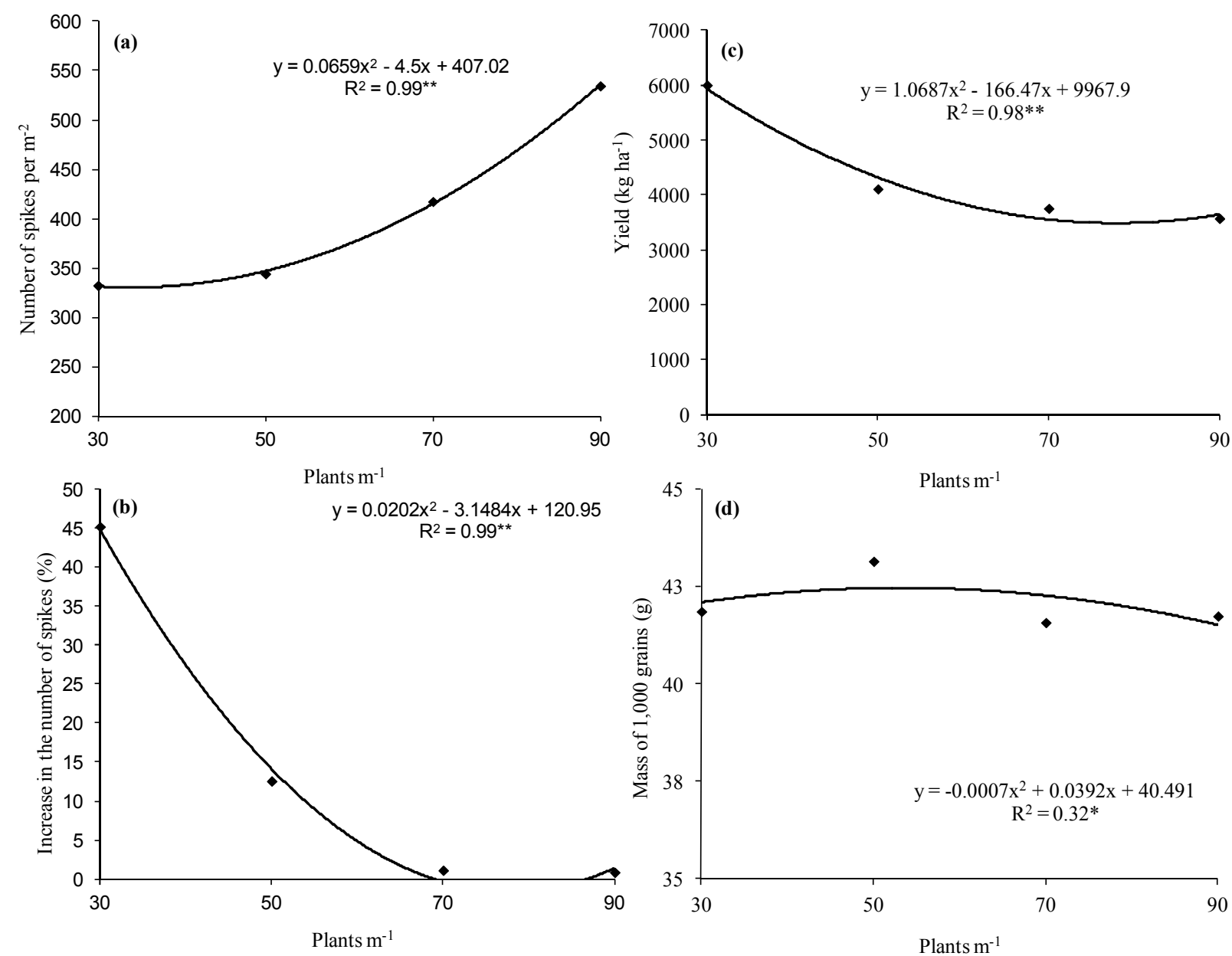

Source: Elaboration of the authors.

Table 4. Variance analysis (F values) number of tillers per $\mathrm{m}^{2}$ before anthesis (TNBA) and harvest (TNH), percentage of fertile tillers (FT\%), Contribution to dry matter accumulation and yield potential of tillers at the end of tillering (1), at anthesis (2) and at harvest (3) affected by plant densities and growth regulators in wheat (IAC 370). Botucatu (SP), Brazil, 2010.

\begin{tabular}{cccccccccc}
\hline & TNBA & TNH & FT $\%$ & MSP $^{1}$ & PP $^{1}$ & MSP $^{2}$ & PP $^{2}$ & MSP $^{3}$ & PP $^{3}$ \\
\hline Bloc & 0,55 & 0,78 & 0,31 & $13,72^{* *}$ & 2,43 & 0,89 & 0,26 & 1,06 & 0,59 \\
Densities (D) & $40,86^{* *}$ & $42,64 * *$ & $23,11^{* *}$ & $277,02^{* *}$ & $7,30^{* *}$ & $112,14^{* *}$ & $15,35^{* *}$ & $174,91 * *$ & $18,54 * *$ \\
Growth regulator (G) & 0,30 & 0,19 & 0,12 & 2,84 & 2,41 & 0,03 & 0,61 & 0,72 & 0,41 \\
D x G & 0,90 & 0,61 & 0,78 & 0,86 & 0,47 & 0,68 & 1,04 & 37,95 & 0,56 \\
\hline CV (\%) & 72,66 & 80,06 & 102,69 & 12,2 & 29,98 & 54,68 & 101,98 & 43,83 & 109,84 \\
CV (\%) & 83,16 & 88,56 & 90,02 & 18,79 & 44,7 & 59,08 & 80,65 & 69,78 & 59,45 \\
\hline
\end{tabular}

$*$ ** Significant by the $\mathrm{F}$ test $\left(\mathrm{p}<0.05\right.$ and $<0.01$ respectively); ${ }^{1}$ plot coefficient of variation; ${ }^{2}$ subplot coefficient of variation. Source: Elaboration of the authors. 
Figure 7. Number of tillers per $\mathrm{m}^{2}$ before anthesis (a) and harvest (b), percentage of fertile tillers (c) affected by plant densities in wheat (IAC 370). Botucatu (SP), Brazil, 2010. ** $p<0.01$.
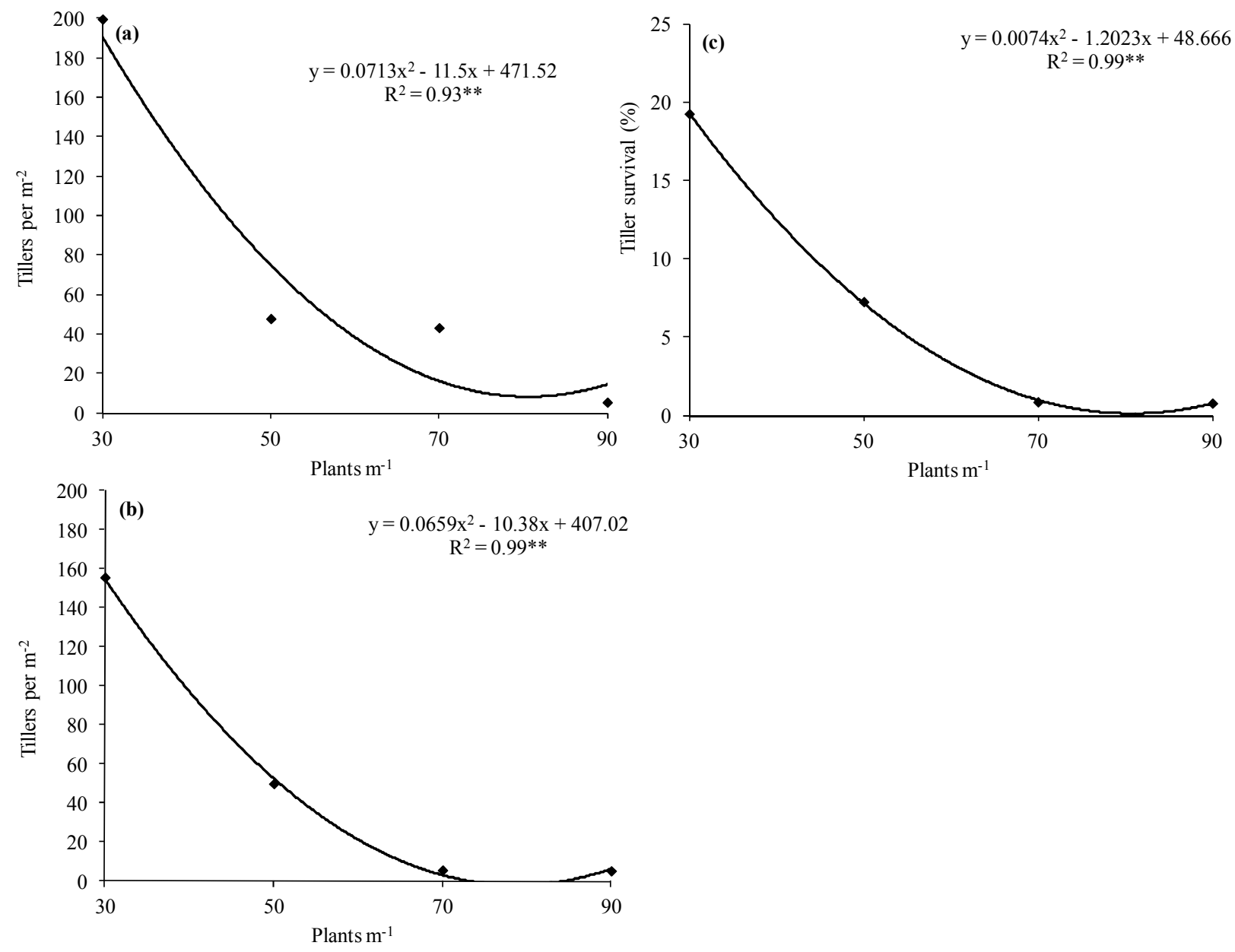

Source: Elaboration of the authors.

According to Figure 7c, low tiller survival was found in the conditions of this experiment. Alves, Mundstock and Medeiros (2000) stated that smallgrain cereals produced in Brazil such as wheat, oat, barley and rye develop a large number of unfertile tillers. Low tiller survival may be affected by physiological conditions of the main stem by the time tillers emerge. Competition effects for photoassimilates in wheat may be reflected on reduced number of tillers per plant or deficient grain filling (VALÉRIO et al, 2008). Tillers are physiologically dependent on the main stem for assimilates, until they show their own completely expanded leaf, and for mineral nutrients, until their roots start developing (SKINER; NELSON, 1994). Nevertheless, it is not entirely clear if assimilates and minerals accumulated in certain tillers can be redistributed to other parts of the plants in case they become non-viable. In this case, unfertile tillers may become reserve organs for plants during their development, preventing losses from abortion.

Contribution of tiller yield in final production of wheat plants is extremely variable according to genotype and environmental conditions (ELHANI et al., 2007). The same authors stated that development of the main stem is prioritized under stress conditions, as also found in this experiment 
(Figure 8). Competition among plants for resources can be observed by comparing both sowing density and evaluation times.

Higher number of plants in the row reduced contribution to assimilate accumulation as well as yield potential of tillers, in all evaluation times. However, there was a little contribution to dry matter accumulation in the end of tillering stage and tillers showed high yield potential, even in the denser population (90 plants $\mathrm{m}^{-1}$ ). This behavior was not observed at anthesis stage and in the end of the cycle; in this case, tiller contribution was null. Even under environments where competition among plants for resources is less intense (e g. lower densities), tiller contribution to dry matter accumulation was reduced until anthesis; average yield potential of tillers compared to the main stem reached maximum $(70 \%)$ by the end of the cycle.

Figure 8. Contribution to dry matter accumulation and yield potential of tillers at the end of tillering (a, b), at anthesis (c, d) and at harvest (e, f) affected by plant densities in wheat (IAC 370). Botucatu(SP), Brazil, $2010 . * * p<0.01$.
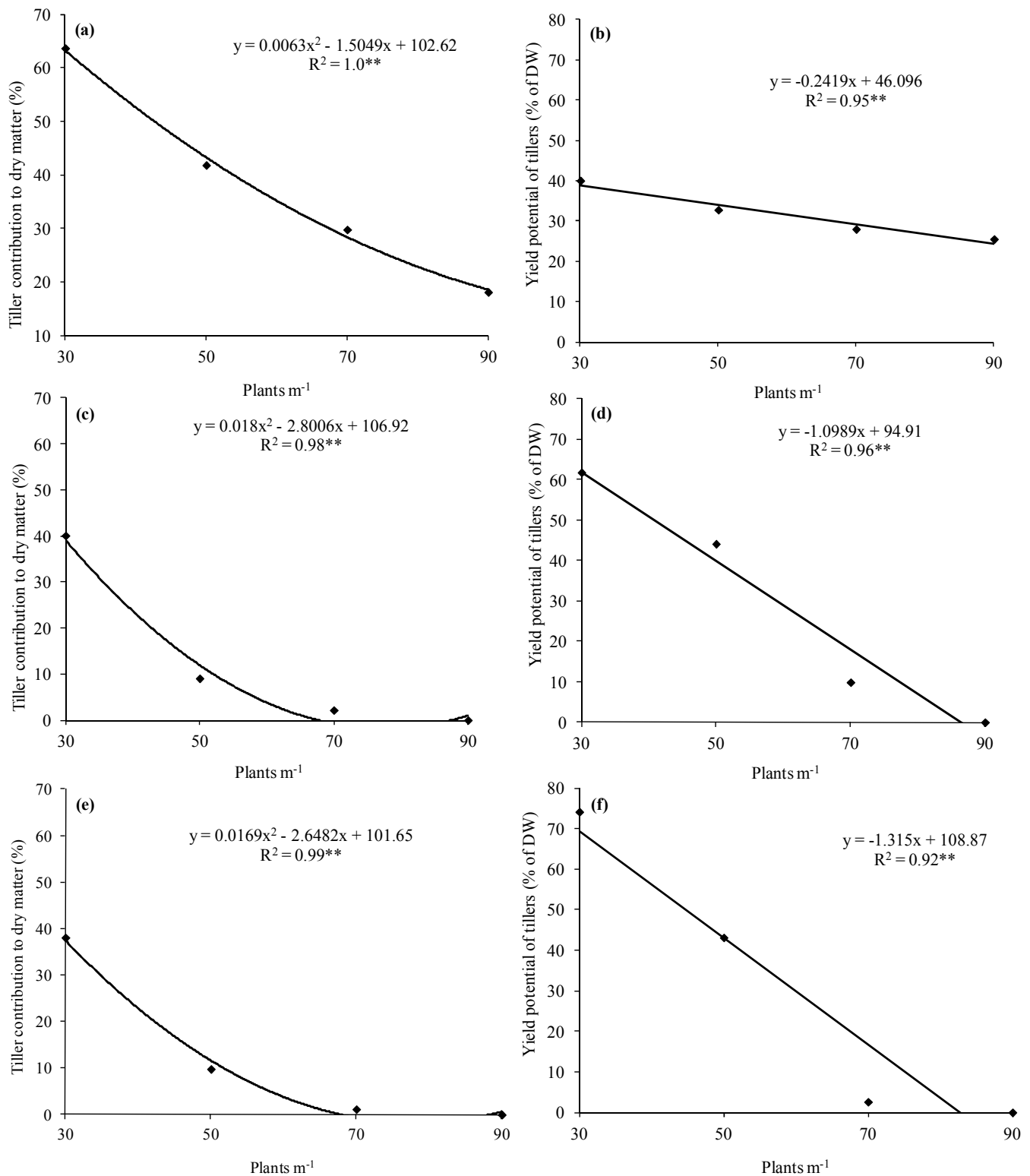

Source: Elaboration of the authors. 


\section{Conclusions}

The application of IBA $+\mathrm{GA}+\mathrm{KT}$ and TrinexapacEthyl, either isolated or combined, does not affect tillering or any other yield parameters related to the main stem of wheat plants;

Reducing in plant densities increase tiller emission, survival and contribution to dry matter accumulation and grain yield in wheat.

Higher grain yield is obtained due to individual yield increases per spike in lower plant densities.

\section{Acknowledgements}

The first author acknowledges a master's degree scholarships granted by FAPESP, Brazil.

\section{References}

ALMEIDA, M. L.; MUNDSTOCK, C. M. A qualidade da luz afeta o afilhamento em plantas de trigo, quando cultivadas sob competição. Ciência Rural, Santa Maria, v. 31, n. 3, p. 401-408, 2001.

ALVES, A. C.; MUNDSTOCK, C. M.; MEDEIROS, J. D. Sistema vascular e controle do desenvolvimento de perfilhos em cereais de estação fria. Revista Brasileira de Botânica, São Paulo, v. 23, n. 1, p. 59-67, 2000.

BALLARÉ, C. L.; SCOPEL, A. L.; SÁNCHEZ, R. A.; RADOSEVICH, S. R. Photomorphogenic processes in the agricultural environment. Photochemistry and Photobiology, Hoboken, v. 56, n. 5, p. 777-788, 1992.

BLUM, A. Improving wheat grain filling under stress by stem reserve mobilization. Euphytica, Wageningen, v. 100, n. 1, p. 77-83, 1998.

BRASIL. Ministério da Agricultura, Pecuária e Abastecimento. Regras para análise de sementes. Ministério da Agricultura, Pecuária e Abastecimento. Secretaria de Defesa Agropecuária. Brasília, DF: Mapa/ ACS, 2009. 395 p.

CRUZ, P. J.; CARVALHO, F. I. F.; SILVA, S. A.; KUREK, A. J.; BARBIERI, R. L.; CARGNIN, A. Influência do acamamento sobre o rendimento de grãos e outros caracteres em trigo. Revista Brasileira de Agrociências, Pelotas, v. 9, n. 1, p. 05-08, 2003.

DESTRO, D.; MIGLIORANZA, E.; ARIAS, C. A. A.; VENDRAME, J. M.; ALMEIDA, J. C. V. Main Stem and Tiller Contribution to Wheat Cultivars Yield Under Different Irrigation Regimes. Brazilian Archives of Biology and Technology, Curitiba, v. 44, n. 4, p. 325-330, 2001.

ELHANI, S.; MARTOS, V.; RHARRABTI, Y.; ROYO, C.; MORAL, L. F. G. Contribution of main stem and tillers to durum wheat (Triticum turgidum $\mathrm{L}$. var. durum) grain yield and its components grown in Mediterranean environments. Field Crops Research, Amsterdam, v. 103, n. 1, p. 25-35, 2007.

EMPRESA BRASILEIRA DE PESQUISA AGROPECUÁRIA - EMBRAPA. Centro Nacional de Pesquisa de Trigo. Informações técnicas para trigo e triticale safra 2011. In: REUNIÃO DA COMISSÃO BRASILEIRA DE PESQUISA DE TRIGO E TRITICALE, 4., Cascavel: COODETEC, 2010. 170 p.

ESPINDULA, M. C.; ROCHA, V. S.; GROSSI, J. A. S.; SOUZA, M. A.; SOUZA, L. T.; FAVARATO, L. F. Use of growth retardants in wheat. Planta Daninha, Viçosa, v. 27, n. 2, p. 379-387, 2009.

FOOD AND AGRICULTURE ORGANIZATION OF THE UNITED NATIONS - FAO. World reference base for soil resources. Rome: FAO, 2006. 128 p.

FREEZE, D. M.; BACON, R. K. Row-spacing and seeding rate effects on wheat yields in the Mid-South. Journal of Production Agriculture, Madison, v. 3, n. 3, p. 345-348, 1990.

HARTWIG, I.; CARVALHO, F. I. F.; OLIVEIRA, A. C.; VIEIRA, E. A.; SILVA, J. A. G.; BERTAN, I.; RIBEIRO, G.; FINATTO, T.; REIS, C. E. S.; BUSATO, C. C. Estimativa de coeficientes de correlação e trilha em gerações segregantes de trigo hexaplóide. Bragantia, Campinas, v. 66, n. 2, p. 203-2018, 2007.

LARGE, E. C. Growth stages in cereals illustration of the feeks scale. Plant Pathology, New York, v. 3, n. 4, p. 128-129, 1954.

LLOVERAS, J.; MANENT, J.; VIUDAS, J.; LÓPEZ, A.; SANTIVERI, P. Tillering rate influence on yield and yield components of irrigated winter wheat in a Mediterranean climate. Agronomy Journal, Madison, v. 96, n. 5, p. 1258-1265, 2004.

MASLE, J. Competition among tillers in winter wheat: consequences for growth and development of the crop. In: DAY, W.; ATKIN, R. K. (Ed.). Wheat growth and modeling. New York: Plenum, 1985. p. 33-54.

NEDEL, J. L. Progresso genético no rendimento de grãos de cultivares de trigo lançadas para cultivo entre $1940 \mathrm{e}$ 1992. Pesquisa Agropecuária Brasileira, Brasília, v. 29, n. 10 , p. $1565-1570,1994$. 
OKUYAMA, L. A.; FERERIZZI, L. C.; BARBOSA NETO, J. F. Correlation and path analysis of yield and its components and plant traits in wheat. Ciência Rural, Santa Maria, v. 34, n. 6, p. 1701-1708, 2004.

OZTURK, A.; CAGLAR, O.; BULUT, S. Growth and yield response of facultative wheat to winter sowing, freezing sowing and spring sowing at different seeding rates. Journal of Agronomy Crop Science, Erzurum, v. 192, n. 1, p. 10-16, 2006.

RODRIGUES, O.; DIDONET, A. D.; LHAMBY, J. C. B.; TEIXEIRA, M. C. C.; DEL DUCA; L. J. Características fisiológicas associadas ao avanço no potencial de rendimento de grãos de trigo. Passo Fundo: Embrapa Trigo, 2002. $26 \mathrm{p}$.

SKINNER, R. H.; NELSON, C. J. Role of leaf appearance rate and the coleoptile tiller in regulating tiller production. Crop Science, Madison, v. 34, n. 1, p. 71-75, 1994.

VALÉRIO, I. P.; CARVALHO, F. I. F.; OLIVEIRA, A. C.; BENIN, G.; SOUZA, V. Q.; MACHADO, A. A.; BERTAN, I.; BUSATO, C. C.; SILVEIRA, G.; FONSECA, D. A. R. Seeding density in wheat genotypes as a function of tillering potential. Scientia Agricola, Piracicaba, v. 66, n. 1, p. 28-39, 2009.
VALÉRIO, I. P.; CARVALHO, F. I. F.; OLIVEIRA, A. C.; MACHADO, A. A.; BENIN, G.; SCHEEREN, P. L.; SOUZA, V. Q.; HARTWIG, I. Desenvolvimento de afilhos e componentes do rendimento em genótipos de trigo sob diferentes densidades de semeadura. Pesquisa Agropecuária Brasileira, Brasília, v. 43, n. 3, p. 319-326, 2008.

VEIT, B. Stem cell signalling networks in plants. Plant Molecular Biology, Zurich, v. 60, n. 6, p. 793-810, 2006.

ZAGONEL, J.; FERNANDES, E. C. Doses e épocas de aplicação do regulador de crescimento afetando cultivares de trigo em duas doses de nitrogênio. Planta Daninha, Viçosa, MG, v. 25, n. 2, p. 331-339, 2007.

ZAGONEL, J.; VENÂNCIO, W. S.; KUNZ, R. P.; TANAMATI, H. Doses de nitrogênio e densidades de plantas com e sem regulador de crescimento afetando o trigo, Cultivar OR-1. Ciência Rural, Santa Maria, v. 32, n. 1, p. 25-29, 2002. 
